\title{
Toxicity of aqueous solutions of cosmetics in phytotest with Lepidium sativum L.
}

\author{
Nataliia Tkachuk ${ }^{1 *}$, Iryna Okulovych ${ }^{2}$ \\ ${ }^{1}$ T.H. Shevchenko National University “Chernihiv Colehium”, Department of Biology, Chernihiv, Ukraine \\ ${ }^{2}$ Uhrynychiv gymnasium, Uhrynychi, Kamin-Kashira district, Volyn region, Ukraine
}

ORCID

Nataliia Tkachuk: https://orcid.org/0000-0002-5115-7716

Iryna Okulovych: https://orcid.org/0000-0001-6221-9866

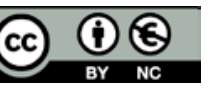

Article Details:

Received:

2021-09-27

Accepted:

2021-11-20

Available online: $2021-11-30$

DOI: https://doi.org/10.15414/ainhlq.2021.0034

Garden cress (Lepidium sativum L.) is a test-plant for studying the toxicity of substrates, which is the basis of phytotesting. Dangerous pollutants are surfactants contained in household chemicals, including cosmetics. The purpose of the work is to investigate the toxicity of cosmetics the micellar water on a phytotest with garden cress and to analyze it for possible effects on human health and the environment. Investigated available in the retail network of Ukraine means for removing makeup and cleansing the skin - micellar water. Seed germination energy ( $3^{\text {rd }}$ day), seed germination, and biometric-morphometric parameters (length of roots and aboveground part of seedlings) ( $5^{\text {th }}$ day) were determined. The results were processed statistically. It was found that the germination rates of garden cress seeds and biometric indicators of seedlings significantly decrease (by 14-100\%) with the increasing concentration of the studied micellar water. The phytotoxic effect ranged from $49.6 \%$ to $100 \%$. It is established that the value of the total toxicity index of solutions is from 0.55 (concentration $6.25 \%$ ) to 0 (concentration $100 \%$ ), indicating an increase in the toxicity of the solution with increasing concentration. Determined that garden cress is a sensitive plant to the studied cosmetic. The obtained data confirm the high efficiency of this test plant for use in biotesting. The phytotest with $L$. sativum established the lethal effect of this cosmetic product at a concentration of $100 \%$. Phytotoxicity decreases when the solution is diluted. Given the results of phytotesting and the composition of the cosmetic product, it can be assumed that at a concentration of $100 \%$ it can pose a potential danger to human health. Given the increase in the market of perfumes and cosmetics, the emergence of counterfeit products, we can expect an increase in the impact of cosmetics on the quality of the environment.

Keywords: Lepidium sativum, micellar water, phytotesting

\section{Introduction}

Garden cress (Lepidium sativum L.) is a recognized sensitive test-plant in bio testing the toxicity of various substrates. Current studies using garden cress reactions are concerned with assessing the toxicity of antibiotics (Tongur and Yildirim, 2015), analgesic drugs (Tongur et al., 2017a), beta-blocker drugs (Tongur et al., 2017b), new derivatives of heterocyclic compounds (Tsekhmister et al., 2012; Tkachuk et al., 2015), urban solid waste compost (Astaraei, 2009), nanoparticles (Jośko et al., 2017; Mielcarz-Skalska and Smolińska, 2018), oil mill wastewater (Dehmani et al., 2020), some shampoos and dishwashing detergents

\footnotetext{
*Corresponding Author: Nataliia Tkachuk, Department of Biology, T.H. Shevchenko National University "Chernihiv Colehium“, 53 Hetman Polubotok Str., 14013 Chernihiv, Ukraine $\triangle$ nataliia.smykun@gmail.com
} 
(Ovsyannikova et al., 2015), heavy metals (Szaniszló and Demény, 2018), microplastics (Bosker et al., 2019; Pflugmacher, et al., 2020, 2021), in particular polyethylene terephthalate microplastics and acid rain (Pignattelli et al., 2021a, b). Most publications examine the level of seed germination, weight, and size of seedlings as test indicators.

Dangerous pollutants are surfactants (Rabosh and Kofanova, 2019). These petrochemical compounds are contained in household chemicals and can reduce the surface tension of water (Frolova et al., 2019). Once in the human body, detergents disrupt the physiological functions of the body due to exposure to enzyme activity (Grabovska et al., 2011). There is evidence that surfactants can affect the human body for a long time due to the properties of gradual accumulation in the brain, liver, heart, subcutaneous tissue (Yuan et al., 2014). That is, they affect the human body comprehensively, not just the skin. The problem is also complicated by the inability of the vast majority of treatment plants in our country to qualitatively remove surfactants and, as a result, their gradual accumulation in the environment (Frolova et al., 2019). Synthetic surfactants, among other organic compounds, are part of cosmetics, in particular micellar water. Therefore, this study aimed to investigate the toxicity of micellar water on a phytotest with garden cress and to analyze it for possible effects on human health and the environment.

\section{Material and methodology}

\section{Test-plant}

Garden cress (L. sativum) of the cultivar Aphrodite of the trademark GL SEEDS (consignment 1148, expiration date 10.2023) was used as a test-plant. The seeds of the test plant before the experiment did not succumb to negative effects and were stored under the same conditions. The seeds were washed with distilled water, then sterilized in $70 \%$ alcohol for $60 \mathrm{~s}$, then carefully washed with sterile distilled water, and then they were used. During the experiment, the energy of seed germination ( $3^{\text {rd }}$ day), seed germination, and biometric-morphometric parameters (length of roots and aboveground part of seedlings) ( $5^{\text {th }}$ day) were determined.

\section{Investigated cosmetic product}

We investigated a means available in the trade network of Ukraine for removing makeup and cleansing the skin - micellar water, which contained (according to the manufacturer): aqua, PEG-40 hydrogenated castor oil, glycerin, Prunus (Amygdalus) dulcis oil, panthenol, sorbitol, decyl glucoside, glyceryl glucoside, poloxamer 124, propylene glycol, disodium cocoyl glutamate, sodium chloride, trisodium EDTA, polyquaternium-10, 1,2-hexanediol, citric acid, sodium acetate, phenoxyethanol. We deliberately do not name the cosmetics used to prevent accusations of advertising or anti-advertising of certain brands.

\section{Toxicity testing}

Seeds of test plants (L. sativum) of 10 pieces were put in Petri dishes on filter paper moistened with distilled water (control) or a suitable aqueous solution of micellar water (experiment). The investigated concentrations of the micellar water were $6.25 \%, 12.5 \%, 25.0 \%, 50.0 \%$ and $100 \%$. The experiment was repeated three times. The incubation temperature of the Petri dishes was $23.0 \pm 2.0^{\circ} \mathrm{C}$. Seed germination energy $\left(3^{\text {rd }}\right.$ day), seed germination, and biometric-morphometric parameters (length of roots and aboveground part of seedlings) $\left(5^{\text {th }}\right.$ day) were determined.

The seed germination index (SGI) and the root length index (RLI) that exemplified phytotoxicity index were described in Eq. (1) and (2):

$$
\begin{gathered}
S G I=\frac{N_{T}(i)-N_{C}}{N_{C}} \\
R L I=\frac{L R_{T}(i)-L R_{C}}{L R_{C}}
\end{gathered}
$$

where:

$\mathrm{N}_{\mathrm{T}}(\mathrm{i})$ and $\mathrm{N}_{\mathrm{C}}$ represent the number of germinated seeds in test (i) and control, and $\mathrm{LR}_{\mathrm{T}}(\mathrm{i})$ and $\mathrm{LR}_{\mathrm{C}}$ refer to the mean root length in test (i) and control respectively. Based on the published empirical value of risk assessment (Bagur-González et al., 2011; Mtisi and Gwenzi, 2019; Cai and Ostroumov, 2021), phytotoxicity can be sorted into four classes such as:

- slight $(-0.25 \leq$ SGI or RLI $<0)$,

- moderate $(-0.5 \leq \mathrm{SGI}$ or $\mathrm{RLI}<-0.25)$,

- high $(-0.75 \leq$ SGI or RLI $<-0.5)$,

- extreme toxicity $(-1 \leq \mathrm{SGI}$ or RLI $<-0.75)$.

The phytotoxic effect (PhTE) and the toxicity index (TI) of the solutions were calculated (Eq. (3) and (4) (Bagdasaryan, 2005):

$$
\operatorname{PhTE}=\left(\frac{\mathrm{L}_{\mathrm{C}}-\mathrm{L}_{\mathrm{T}}(\mathrm{i})}{\mathrm{L}_{\mathrm{C}}}\right) \times 100
$$




$$
\mathrm{TI}=\left(\frac{\mathrm{N}_{\mathrm{T}}(\mathrm{i})}{\mathrm{N}_{\mathrm{C}}}+\frac{\mathrm{LA}_{\mathrm{T}}(\mathrm{i})}{\mathrm{LA}_{\mathrm{C}}}+\frac{\mathrm{LR}_{\mathrm{T}}(\mathrm{i})}{\mathrm{LR}_{\mathrm{C}}}\right) \div 3
$$

where:

$\mathrm{N}_{\mathrm{T}}(\mathrm{i})$ and $\mathrm{NC}$ represent the number of germinated seeds in the test (i) and control, $\mathrm{LA}_{\mathrm{T}}(\mathrm{i})$ and $\mathrm{LA}_{\mathrm{C}}$ refer to the mean length of the aboveground part in the test (i) and control, and $\mathrm{LR}_{\mathrm{T}}(\mathrm{i})$ and $\mathrm{LR}_{\mathrm{C}}$ refer to the mean root length in the test (i) and control, respectively

\section{Statistical analysis}

Basic statistical analyses were performed using PAST 2.17 (Norway, 2001); the results are expressed as mean values of three replications \pm standard deviation (SD) and differences between means compared through the Tukey-Kramer test $(\mathrm{p}<0.05)$.

\section{Results and discussions}

\section{Test-indicators of $L$. sativum}

Various plants, including Allium cepa L. (Srivastava and Singh, 2020; Souza et al., 2020; Macar, 2021), Lactuca sativa L. (Lyu et al., 2018; Mtisi and Gwenzi, 2019; Gao et al., 2021), L. sativum (Szaniszló and Demény, 2018; Bosker et al., 2019; Pflugmacher et al., 2020, 2021; Pignattelli et al., 2021a, b), are used in phytotoxicity studies of malathion, tetraconazole, nanoparticles, heavy metals, phenol, effluents, receiving water, coal ash, polyethylene particles, microplastics. In the studies of testing solutions toxicity are used following parameters of these plants: germination and radicle elongation (Mtisi and Gwenzi, 2019), germination, the root, the shoot, and the overall seedlings length, the roots and shoots' fresh and dry weight, the pigment $\mathrm{Chl} \mathrm{a}$ and $\mathrm{Chl} \mathrm{b}$ content, catalase activity (Pflugmacher et al., 2021).
In our studies, we used germination energy, seed germination, aboveground part length, and seedling root length as the test indicators, due to their availability, ease of measurement, and sensitivity to toxic effects (Pflugmacher et al., 2020, 2021). The results of the study of test parameters of L. sativum under the influence of micellar water are shown in Table 1.

It was found that the germination energy and germination of garden cress seeds when watered with the studied solutions of micellar water significantly decreased compared to the control: by $12 \%$ (at a concentration of $6.25 \%$ ), by $25 \%$ (at a concentration of $12.5 \%$ ), by $18 \%$ (at a concentration of $25.0 \%$ ), by $36 \%$ (at a concentration of $50.0 \%$ ). Decreased germination of garden cress was also observed under the influence of a number of chemical compounds, in particular, heavy metals (Nouri and Haddioui, 2021), saline solutions (Uçarll, 2020), some essential oils (Abd-ElGawad et al., 2021). In the latter case, researchers are even discussing potential herbicidal activity essential oils.

At the same time, there are reports of insensitivity of seeds germination to the action of toxicants, such as coal ash (Mtisi and Gwenzi, 2019) and nanomaterials (Bouguerra et al., 2016; Gavina et al., 2016; Soares et al., 2016).

In our study, when watering L. sativum seeds with a solution with the maximum test concentration (100\%), it did not germinate. This fact is probably related to both the osmotic stress for the plant (Uçarll, 2020) and/or the chemical composition of the cosmetic product under study.

The biometric and morphometric parameters of garden cress also decreased with the increasing concentration of the studied cosmetic product. The

Table 1 Seed germination rates and biometric indicators of Lepidium sativum L. seedlings under the influence of aqueous solutions of micellar water

\begin{tabular}{lcccc}
\hline $\begin{array}{l}\text { The concentration of } \\
\text { the test compound (\%) }\end{array}$ & $\begin{array}{c}\text { Seed germination } \\
\text { energy (\%) }\end{array}$ & $\begin{array}{c}\text { Seed germination } \\
\mathbf{( \% )}\end{array}$ & $\begin{array}{c}\text { Length of the } \\
\text { aboveground part (mm) }\end{array}$ & $\begin{array}{c}\text { Length of roots } \\
\text { (mm) }\end{array}$ \\
\hline $\mathbf{0}$ (control) & $93.3 \pm 3.3$ & $93.3 \pm 3.3$ & $23.8 \pm 0.5$ & $10.0 \pm 0.3$ \\
$\mathbf{6 . 2 5}$ & $80.0 \pm 0.0^{*}$ & $80.0 \pm 0.0^{*}$ & $12.0 \pm 0.3^{*}$ & $8.2 \pm 0.3^{*}$ \\
$\mathbf{1 2 . 5}$ & $70.0 \pm 0.0^{*}$ & $70.0 \pm 0.0^{*}$ & $* * *$ & $6.1 \pm 0.3^{*}$ \\
$\mathbf{2 5 . 0}$ & $70.0 \pm 0.0^{*}$ & $76.7 \pm 3.3^{*}$ & $* * *$ & $3.8 \pm 0.2^{*}$ \\
$\mathbf{5 0 . 0}$ & $60.0 \pm 0.0^{*}$ & $60.0 \pm 0.0^{*}$ & $* * *$ & $3.0 \pm 0.3^{*}$ \\
$\mathbf{1 0 0}$ & $* *$ & $* *$ & $* *$ & $* *$ \\
\hline
\end{tabular}

Note: ${ }^{*}$ differences from control are significant at $\mathrm{p} \leq 0.05$; ${ }^{* *}$ the indicator was not measured because the seeds did not germinate; ${ }^{* * *}$ the indicator was not measured because the seedlings did not have the appropriate parts 
length of the aboveground part of garden cress seedlings was determined only for control and variant with a concentration of micellar water of $6.25 \%$. In this case, the length of the aboveground part of the seedlings was 2 times significantly less than in the control. At concentrations greater than $6.25 \%$, the aboveground part of L. sativum seedlings was absent. A statistically significant decrease compared to the control was observed in the length of the roots: by $18 \%$ (at a concentration of $6.25 \%$ ), by $39 \%$ (at a concentration of $12.5 \%$ ), by $62 \%$ (at a concentration of $25.0 \%$ ), by $70 \%$ (at a concentration of $50 \%$ ). The decrease in the length of the roots/aboveground part of the seedlings of test plants with increasing concentration of solutions studied for their toxicity, noted by other researchers (Seneviratne et al., 2017; Nedjimi, 2020; Pflugmacher et al., 2020, 2021; Macar, 2021).

\section{Phytotoxicity indices}

In phytotests, various indices are calculated to evaluate the results. For example, calculate the percentages of relative seed germination, relative root growth, germination index (Pampuro et al., 2017), germination percentage, germination index, germination rate index, vigor index, coefficient of the velocity of germination and mean germination time (Nouri et al., 2020). Mtisi and Gwenzi (2019) note that positive seed germination index and root length index values indicate stimulation of germination or growth, while negative values denote phytotoxicity.

Based on the obtained data, we calculated the phytotoxicity indices of aqueous solutions of the studied micellar water, which are shown in Table 2.
According to the calculated phytotoxic indices, it was found that the toxicity of the studied solutions to garden cress increases with the increasing concentration of micellar water in them.

Micellar water is considered as the main biologically active compound of cosmetics (Korytniuk et. Al., 2019). At the same time, the composition of the studied cosmetic micellar water is alarming due to the content of surfactants, which toxic effect on living organisms is known. The molecular mechanisms of the biological effects of detergents include interaction with biological membranes (Cai and Ostroumov, 2021). Particularly dangerous to human health are PEG, propylene glycol (The "Dirty Dozen" ingredients..., 2010), trisodium EDTA (Safety assessment of EDTA..., 2019). PEGs (polyethylene glycols) are petroleumbased compounds that are widely used in cream bases for cosmetics as thickeners, solvents, softeners, and moisture carriers (The "Dirty Dozen" ingredients..., 2010). Some reports depending on manufacturing processes, PEGs may be contaminated with measurable amounts of 1,4-dioxane (a possible human carcinogen). (The "Dirty Dozen" ingredients..., 2010). It is indicated: "While carcinogenic contaminants are the primary concern, PEGs themselves show some evidence of genotoxicity and if used on broken skin can cause irritation and systemic toxicity. The industry panel that reviews the safety of cosmetics ingredients concluded that some PEGs are not safe for use on damaged skin (although the assessment generally approved the use of these chemicals in cosmetics). Also, PEGs function as "penetration enhancers", increasing the permeability of the skin to allow greater absorption of the

Table 2 Indices of phytotoxicity of aqueous solutions of micellar water

\begin{tabular}{|c|c|c|c|c|c|c|}
\hline $\begin{array}{l}\text { The concentration of } \\
\text { the test compound }(\%)\end{array}$ & SGI & RLI & PhTE & TI & $\begin{array}{l}\text { Interpretation of the } \\
\text { results of phytotest }\end{array}$ & Comments \\
\hline 0 (control) & 0.00 & 0.00 & 0 & 1.00 & no toxicity & no inhibition of growth \\
\hline 6.25 & -0.14 & -0.18 & 18 & 0.73 & slight toxic effect & a slight inhibition of growth \\
\hline 12.5 & -0.25 & -0.39 & 39 & 0.45 & a pronounced toxicity & $\begin{array}{l}\text { inhibition of growth almost } \\
50 \% \text {, no aboveground part } \\
\text { growth observed }\end{array}$ \\
\hline 25.0 & -0.18 & -0.62 & 62 & 0.40 & strong toxicity & $\begin{array}{l}\text { inhibition of growth more than } \\
50 \% \text {, no aboveground part } \\
\text { growth observed }\end{array}$ \\
\hline $\mathbf{5 0 . 0}$ & -0.36 & -0.70 & 70 & 0.37 & strong toxicity & $\begin{array}{l}\text { inhibition of growth more than } \\
50 \% \text {, no aboveground part } \\
\text { growth observed }\end{array}$ \\
\hline 100 & -1.00 & -1.00 & 100 & 0.00 & $\begin{array}{l}\text { lethal effect, extreme } \\
\text { toxicity }\end{array}$ & $\begin{array}{l}\text { no seed germination, no } \\
\text { aboveground part, and root } \\
\text { growth observed }\end{array}$ \\
\hline
\end{tabular}

Note: SGI - the seed germination index; RLI - the root length index; PhTE - the phytotoxic effect; TI - the toxicity index 
product - including potentially harmful ingredients". (The "Dirty Dozen" ingredients..., 2010). Propylene glycol functions as a penetration enhancer can allow harmful ingredients to be absorbed more readily through the skin (The "Dirty Dozen" ingredients..., 2010). Lanigan and Yamarik (2002) based on the analysis of publications indicate that EDTA and its salts have been evaluated for the potential to cause chromosomal aberrations, semilethals, crossovers, forward mutations, replicative DNA synthesis, DNA strand breaks, dominant lethal, inhibition of metabolic cooperation and contact feeding, and sister-chromatid exchanges with mostly negative results. However, there are positive results, references to publications cited by these authors.

Regarding the impact of the components of the studied tool on the environment, the available scientific and methodological base contains only a few reports. Thus, it is reported that EDTA may contribute to aquatic toxicity at low concentrations and its release into natural waters should be minimized wherever possible (Sillanpää, 1997; Oviedo and Rodrígues, 2003). In the publications, the following components of cosmetics are considered as wastewater contaminants: phthalates, triclosan, bisphenol A (Water pollution..., 2007), microplastics, UV filters, some preservatives (parabens, triclosan) (Juliano and Magrini, 2017). But these chemical compounds are not specified in the composition. In general, aqueous solutions of investigated cosmetics at a concentration of $6.25 \%$ had a weak toxic effect. However, in Ukraine and the world there is a steady increase in the market share of perfumes and cosmetics (Dobrovolskyi and Lohvynenko, 2018), the global micellar water market is projected to grow from 112.3 million U.S. dollars in 2017 to 184 million dollars in 2023 (Ridder, 2020). Currently, the Ukrainian market of cosmetic products is considered the second in the world after China in terms of sales of counterfeit products that do not meet sanitary and hygienic safety (Baitsar and Kordiiaka, 2015).

\section{Conclusions}

Thus, it was found that undiluted micellar water is extremely toxic to the test plant L. sativum. The phytotest established the lethal effect on phytotest of this cosmetic product at a concentration of $100 \%$. Phytotoxicity decreases when the solution is diluted. Given the results of phytotesting and the composition of the cosmetic product, it can be assumed that at a concentration of $100 \%$ it can pose a potential danger to human health. Given the increase in the market of perfumes and cosmetics, the emergence of counterfeit products, we can expect an increase the impact of cosmetics on the quality of environment.

\section{Conflicts of interest}

The authors declare no conflict of interest.

\section{Ethical statement}

This article does not contain any studies that would require an ethical statement.

\section{References}

Abd-Elgawad, A.M., El Gendy, A.E.-N.G., Assaeed, A.M., AlRowaily, S.L., Alharthi, A.S., Mohamed, T.A., Nassar, M.I., Dewir, Y.H., \& Elshamy, A.I. (2021). Phytotoxic effects of plant essential oils: a systematic review and structureactivity relationship based on chemometric analyses. Plants, 10, 36.

https://dx.doi.org/10.3390/plants10010036

Astaraei, A.R. (2009). Toxicity evaluation of different urban solid waste compost on germination and growth parameters of Lepidium sativum L. In Chemical, Biological and Environmental Engineering. Proceedings of the International Conference on CBEE 2009, Singapore (9-11 October 2009).

Bagdasaryan, A.S. (2005). Biotestirovaniye pochv tekhnogennykh zon gorodskikh territoriy $\mathrm{s}$ ispol'zovaniyem rastitel'nykh organizmov [Biotesting of soils in technogenic zones of urban areas using plant organisms]: dis. kand.biol.nauk: 03.00.16/Bagdasaryan Aleksandr Sergeyevich. Stavropol'. [in Russian]

Bagur-González, M.G., Estepa-Molina, C., Martín-Peinado, F., \& Morales-Ruano, S. (2011). Toxicity assessment using Lactuca sativa L. bioassay of the metal(loid)s As, $\mathrm{Cu}, \mathrm{Mn}$, $\mathrm{Pb}$ and $\mathrm{Zn}$ in soluble-in-water saturated soil extracts from an abandoned mining site. Journal of Soils and Sediments, 11, 281-289.

Baitsar, R.I., \& Kordiiaka, Yu.M. (2015). Aktualni problemy ta perspektyvy rozvytku kosmetychnoi haluzi. [Elektronnyi resurs]. [Current problems and prospects for the development of the cosmetics industry. [Electronic resource]. http://ena.lp.edu.ua/bitstream/ ntb/31203/1/09-44-49.pdf [in Ukrainian]

Bosker, T., Bouwman, L.J., Brun, N.R., Behrens, P., \& Vijver, M.G. (2019). Microplastics accumulate on pores in seed capsule and delay germination and root growth of the terrestrial vascular plant Lepidium sativum. Chemosphere, 226, 774-781.

https://doi.org/10.1016/j.chemosphere.2019.03.163

Bouguerra, S., Gavina, A., Ksibi, M., Da Graça Rasteiro, M., Rocha-Santos, T., \& Pereira, R. (2016). Ecotoxicity of titanium silicon oxide (TiSiO4) nanomaterial for terrestrial plants and soil invertebrate species. Ecotoxicol. Environ. Saf., 129, $291 \mathrm{e} 301$.

Cai, X. \& Ostroumov, S.A. (2021). Finding of toxicity of herbal shampoo to plant seedlings: phytotest of mixture 
product that contains membranotropic chemicals as components. Ecologica, 28(101), 6-10.

Dehmani, Y., Ed-Dra, A., Zennouhi, O., Bouymajane, A., Filali, F.R., Nassiri, L., \& Abouarnadasse, S. (2020). Chemical characterization and adsorption of oil mill wastewater on Moroccan clay in order to be used in the agricultural field. Heliyon. 6(1), e03164. https://doi.org/10.1016/j.heliyon.2020.e03164.

Dobrovolskyi, V.V., \& Lohvynenko, V.I. (2018). Otsinka rynku parfumerno-kosmetychnykh tovariv [Evaluation of the perfume and cosmetics market]. Ekonomika i suspilstvo, 15, 120-123. [in Ukrainian]

Frolova, T.V., Miasoiedov, V.V., Atamanova, O.V., Siniaieva, I.R., \& Stenkova, N.F. (2019). Vplyv zasobiv pobutovoi khimii, shcho mistiat poverkhnevo aktyvni rechovyny na stan zdorovia ditei (Chastyna I) [Influence of household chemicals containing surfactants on children's health (Part I)]. Ukrainskyi zhurnal medytsyny, biolohii ta sportu, 4(6), 211-216. [in Ukrainian]

Gao, M., Liu, Y., Dong, Y., \& Song, Z. (2021). Effect of polyethylene particles on dibutyl phthalate toxicity in lettuce (Lactuca sativa L.). J. Hazard. Mater., 401, 123422. https://doi.org/10.1016/i.jhazmat.2020.123422.

Gavina, A., Bouguerra, S., Lopes, I., Marques, C.R., Rasteiro, M.G., Antunes, F., Rocha-Santos, T., \& Pereira, R. (2016). Impact of organic nano-vesicles in soil: the case of sodium dodecyl sulphate/didodecyl dimethylammonium bromide. Sci. Total Environ., 547, 413e421.

Grabovska, O.S., Grabovskyy, S.S., \& Kaplinskyy, V.V. (2011). Vplyv poverkhnevo aktyvnykh rechovyn na zhyvyy organism [The effect of surfactants on a living organism]. Lvivska politekhnika, 5, 43-52. [in Ukrainian]

Jośko, I., Oleszczuk, P., \& Skwarek, E. (2017). Toxicity of combined mixtures of nanoparticles to plants. Journal of Hazardous Materials, 331, 200-209. https://doi.org/10.1016/j.jhazmat.2017.02.028

Juliano, C., \& Magrini, G.A. (2017). Cosmetic ingredients as emerging pollutants of environmental and health concern. A Mini-Review. Cosmetics, 4(2), 11. https://doi.org/10.3390/cosmetics4020011

Korytniuk, R.S., Davtian, L.L., Hudz, N.F., Drozdova, A.O., Vlasenko, I.O., Leleka, M.V., \& Olifirova, T.F. (2019). Medyko-biolohichna funktsiia vody [Medical and biological function of water]. Farmatsevtychnyi zhurnal, 3, 65-75. [in Ukrainian]

Lanigan, R.S., \& Yamarik, T.A. (2002). Final report on the safety assessment of EDTA, calcium disodium EDTA, diammonium EDTA, dipotassium EDTA, disodium EDTA, TEA-EDTA, tetrasodium EDTA, tripotassium EDTA, trisodium EDTA, HEDTA, and trisodium HEDTA. International Journal of Toxicology, 21(2), 95-142. https://doi.org/10.1080/10915810290096522.

Lyu, J., Park, J., Kumar Pandey L., Choi, S., Lee, H., De Saeger, J., Depuydt, S., \& Han, T. (2018). Testing the toxicity of metals, phenol, effluents, and receiving waters by root elongation in Lactuca sativa L. Ecotoxicology and Environmental Safety, 149, 225-232.

https://doi.org/10.1016/j.ecoenv.2017.11.006.
Macar, O. (2021). Multiple toxic effects of tetraconazole in Allium cepa L. meristematic cells. Environmental Science and Pollution Research, 28, 10092-10099. https://doi.org/10.1007/s11356-020-11584-4

Mielcarz-Skalska, L., \& Smolińska, B. (2018). Response of Lepidium sativum to soil contamination with zinc in molecular and nanoparticle form. World Scientific News, 114, 55-67.

Mtisi, M., \& Gwenzi, W. (2019). Evaluation of the phytotoxicity of coal ash on lettuce (Lactuca sativa L.) germination, growth and metal uptake. Ecotoxicology and Environmental Safety, 170, 750-762.

Nedjimi, B. (2020). Germination characteristics of Peganum harmala L. (Nitrariaceae) subjected to heavy metals: implications for the use in polluted dryland restoration. International Journal of Environmental Science and Technology, 17, 2113-2122. https://doi.org/10.1007/s13762-019-02600-3

Nouri, M., \& Haddioui, A. (2021). Improving seed germination and seedling growth of Lepidium sativum with different priming methods under arsenic stress. Acta Ecologica Sinica, 41(1), 64-71. https://doi.org/10.1016/j.chnaes.2020.12.005

Nouri, M., El Rasafi, T., \& Haddioui, A. (2020). Lepidium sativum L. Hormesis induced by heavy metal stress for seed germination and seedling growth. Journal of Applied Science and Environmental Studies, 3(4), 218223. http://orcid.org/0000-0002-5751-8949

Oviedo, C.,\&Rodrígues, J. (2003). EDTA: the chelating agentunder environmental scrutiny. Química Nova, 26(6), 901-905. https://doi.org/10.1590/S0100-40422003000600020

Ovsyannikova, I.V., Fanakova, N.N., \& Khayrullin, R.M. (2015). Opredeleniye toksichnosti sredstv bytovoy khimii $\mathrm{s}$ ispol'zovaniyem semyan kress-salata (Lepidium sativum). [Determination of the toxicity of household chemicals using garden cress seeds (Lepidium sativum)]. In Aktual'nyye problemy regional'noy ekologii i biodiagnostika zhivykh sistem: Materialy XIII Vserossiyskoy nauchno-prakticheskoy konferentsii c mezhdunarodnym uchastiyem. Kniga 2. Kirov: Izdatel'stvo 000 «Vesi». [in Russian]

Pampuro, N., Bisaglia, C., Romano, E., Brambilla, M., Foppa Pedretti, E., \& Cavallo, E. (2017). Phytotoxicity and chemical characterization of compost derived from pig slurry solid fraction for organic pellet production. Agriculture, 7, 94. https://doi.org/10.3390/agriculture7110094

Pflugmacher, S., Sulek, A., Mader, H., Heo, J., Noh, J.H., Penttinen, O.-P., Kim, Y., Kim, S., \& Esterhuizen, M. (2020). The influence of new and artificial aged microplastic and leachates on the germination of Lepidium sativum L. Plants, 9, 339. https://doi.org/10.3390/plants9030339.

Pflugmacher, S., Tallinen, S., Kim, Y. J., Kim, S., \& Esterhuizen, M. (2021). Ageing affects microplastic toxicity over time: Effects of aged polycarbonate on germination, growth, and oxidative stress of Lepidium sativum. Science of The Total Environment, 790, 148166. https://doi.org/10.1016/j.scitotenv.2021.1481 
Pignattelli, S., Broccoli, A., Piccardo, M., Felline, S., Terlizzi, A., \& Renzi, M. (2021b). Short-term physiological and biometrical responses of Lepidium sativum seedlings exposed to PET-made microplastics and acid rain. Ecotoxicology and Environmental Safety, 208, 111718. https://doi.org/10.1016/i.ecoenv.2020.111718.

Pignattelli, S., Broccoli, A., Piccardo, M., Terlizzi, A., \& Renzi, M. (2021a). Effects of polyethylene terephthalate (PET) microplastics and acid rain on physiology and growth of Lepidium sativum. Environmental Pollution, 1(282), 116997. https://doi.org/10.1016/j.envpol.2021.116997.

Rabosh, I.O., \& Kofanova, O.V. (2019). Ekolohichna nebezpeka zastosuvannia syntetychnykh myiuchykh zasobiv [Ecological danger of using synthetic detergents]. https://conf. ztu.edu.ua/wp-content/ uploads/2019/12/18.pdf. [in Ukrainian]

Ridder, M. (2020). Global micellar water market value 20172023. https://www.statista.com/statistics/863223/ global-micellar-water-market-value/

Safety Assessment of Edta \& Salts as Used in Cosmetics. (2019). 77 p.

https://www.cir-safety.org/sites/default/files/EDTA.pdf

Seneviratne, M., Rajakaruna, N., Rizwan, M., Madawala, H.M.S.P., Ok, Y.S., \& Vithanage, M. (2017). Heavy metal-induced oxidative stress on seed germination and seedling development: a critical review. Environ. Geochem. Health, 41(4), 1813-1831. https://doi. org/10.1007/s1065 3-017-0005-8

Sillanpää, M. (1997). Environmental fate of EDTA and DTPA. Reviews of Environmental Contamination and Toxicology, 152, 85-111. https://doi.org/10.1007/978-1-4612-1964-4 3.

Soares, C., Branco-Neves, S., De Sousa, A., Pereira, R., \& Fidalgo, F. (2016). Ecotoxicological relevance of nano-NiO and acetaminophen to Hordeum vulgare L.: combining standardized procedures and physiological endpoints. Chemosphere, 165, 442-452.

Souza, I.R., Silva, L.R., Fernandes, L.S.P., Salgado, L.D., Silva De Assis, H.C., Firak, D.S., Bach, L., Santos-Filho, R., Voigt, C.L., Barros, A.C., Peralta-Zamora, P., Mattoso, N., Franco, C.R.C., Soares Medeiros, L.C., Marcon, B.H., Cestari, M.M., Sant'anna-Santos, B.F., \& Leme, D.M. (2020). Visiblelight reduced silver nanoparticles' toxicity in Allium cepa test system. Environmental Pollution, 257, 113551. https://doi.org/10.1016/i.envpol.2019.113551.;

Srivastava, A.K., \& Singh, D. (2020). Assessment of malathion toxicity on cytophysiological activity, DNA damage and antioxidant enzymes in root of Allium cepa model. Scientific Reports, 10, 886. https://doi.org/10.1038/s41598-020-57840-y;

Szaniszló, A., \& Demény, K. (2018). Evolution of the absorption of heavy metals in function of nutrients. Columella - Journal of Agricultural and Environmental Sciences, 5(1), 37-44.
https://doi.org/10.18380/SZIE.COLUM.2018.5.1.37.

The "Dirty Dozen" Ingredients Investigated In The David Suzuki Foundation Survey Of Cosmetics. (2010). 19 p. https://davidsuzuki.org/wp-content/ uploads/2017/10/dirty-dozen-cosmetics-ingredientsbackgrounder.pdf.

Tkachuk, N.V., Yanchenko, V.A., \& Demchenko, A.M. (2015). Antibakterial'naya i fitotoksicheskaya aktivnost' proizvodnykh antipirina s imidazoazepinovym fragmentom [Antibacterial and phytotoxic activity of antipyrine derivatives with an imidazoazepine fragment]. Vestnik BGU. Seriya 2. Biologiya. Khimiya. Geografiya, 1, 38-43. [in Russian]

Tongur, S., \& Yildirim, R. (2015). Acute toxicity assessment of antibiotics in water by luminescence bacteria and Lepidium sativum. Procedia Earth and Planetary Science, $15,468-473$.

Tongur, S., Yildiz, S., Ünal, A., Atalay, K., \& Yeniköşker, M. (2017a). Toxicity assessment of analgesics by Lepidium sativum toxicity test method. In Digital Proceeding of ICOCEE - CAPPADOCIA2017. S. Sahinkaya and E. Kalıpcl (Editors). Nevsehir, Turkey.

Tongur, S., Yildiz, S., Ünal, A., Atalay, K., Yeniköşker, M. (2017b). Toxicity assessment of beta-blocker drug by Lepidium sativum toxicity test method. In Digital Proceeding of ICOCEE - CAPPADOCIA2017. S. Sahinkaya and E. Kalıpcl (Editors). Nevsehir, Turkey.

Tsekhmister, A.V., Pinchuk, L.A., Tkachuk, N.V., Yanchenko, V.O., \& Demchenko, A.M. (2012). Pokaznyky rostu Lepidium sativum L. za prysutnosti 1-aryltetrazolvmistnykh pokhidnykh 1-tetralin-6-il-etanonu [Growth rates of Lepidium sativum L. in the presence of 1-aryltetrazolecontaining derivatives of 1-tetralin-6-yl-ethanone]. Naukovi zapysky Ternopilskoho natsionalnoho pedahohichnoho universytetu im. V.Hnatiuka. Seriia: Biolohiia, 3(52), 84-88. [in Ukrainian]

Uçarli, C. (2020). Effects of salinity on seed germination and early seedling stage, abiotic stress in plants. In Shah Fahad, Shah Saud, Yajun Chen, Chao Wu and Depeng Wang (Eds), Abiotic stress in plants. IntechOpen. https://doi.org/10.5772/intechopen.93647

Water Pollution Caused By Cosmetic Chemicals, Cleaning Supplies And Plastics. (2007). 43 p. https://www.issuelab.org/resources/9038/9038.pdf.

Yuan, C.L., Xu, Z.Z., Fan, M.X., Liu, H.Y., \& Xie, Y.H. (2014). Study on characteristics and harm of surfactants. Journal of Chemical and Pharmaceutical Research, 6(7), 2233-2237. 